\title{
The Impact of the COVID-19 Pandemic on Women Working in Higher Education
}

\author{
Jo Augustus* \\ Senior Lecturer, School of Allied Health and Community, Department of Health and Well-Being, The University of Worcester, \\ Worcester, United Kingdom
}

Keywords: childcare, COVID-19 pandemic, women, remote learning, division of labour, higher education, burden

\section{INTRODUCTION}

In response to the COVID-19 pandemic in March 2020 many organisations, including universities, requested employees to work remotely. Subsequently the education sector saw a rapid move away from classroom-based pedagogies towards distance learning (Aldossari and Chaudhry, 2021). It has been recognised that the impact of the COVID-19 pandemic on men and women is different (Yildirim and Eslen-Ziya, 2020). This is no different in Higher Education. With the closure of schools and pre-schools, women with children were faced with a sudden increase in childcare responsibilities and household labour (Yildirim and Eslen-Ziya, 2020). Domestic roles and responsibilities appear to become less defined, the boundary between home and work became increasingly blurred (Alon et al., 2020; Cui et al., 2020; Yildirim and Eslen-Ziya, 2020). Household living spaces were transformed into

OPEN ACCESS

Edited by: Geneviève Pagé,

University of Quebec in Outaouais,

Canada

Reviewed by: Eva Lantsoght,

Universidad San Francisco de Quito,

Ecuador

${ }^{*}$ Correspondence:

Jo Augustus

j.augustus@worc.ac.uk

Specialty section: This article was submitted to Educational Psychology, a section of the journal

Frontiers in Education

Received: 31 December 2020 Accepted: 27 April 2021 Published: 14 May 2021

Citation:

Augustus J (2021) The Impact of the COVID-19 Pandemic on Women

Working in Higher Education.

Front. Educ. 6:648365.

doi: 10.3389/feduc.2021.648365 places of learning, childcare and work (Clark et al., 2020). There are indications that divisions widened during the COVID-19 pandemic (Guatimosim, 2020; Minello, 2020).

Women already faced with the burden of educating children coupled with their own employment, saw a sudden increase of childcare responsibilities and household labour forced by the lockdown. This created work/family conflict and was more apparent to women (Alon et al., 2020; Biroli et al., 2020; Carlson et al., 2020; Costoya et al., 2020; Power, 2020). This is likely to have led to a decrease in engagement with paid employment, necessitating that women increase their overall workloads to meet these emerging demands (Wang and Inoue, 2020; Yildirim and Eslen-Ziya, 2020). Gender inequality within the household is not a new concept; it is often noted as being two-fold, historically known as the double burden (Hochschild and Machung, 2012). Research indicates that having children is an important precursor to changes in workload (Yildirim and Eslen-Ziya, 2020). The impact is wide-reaching, leading to a decrease in psychological wellbeing and health difficulties, as well as limiting career development and progression (Blau and DeVaro, 2007; Yildirim and EslenZiya, 2020). The following will explore whether or not the advent of COVID-19 pandemic and the resultant changes to working practices have exacerbated these existing gender inequalities.

\section{ROLES AND RESPONSIBILITIES}

There are well documented and researched inequalities between men and women in the workplace which existed long before the COVID-19 pandemic (Yildirim and Eslen-Ziya, 2020). These inequalities stem in part from women's role as mother and provider of childcare, and also through idealised societal norms such as those associated with appearance. Women are more likely than men to take career breaks associated with childcare, this places them at a double bind. They may fall behind their peers in what remains traditional linear career progression models and also have to take time in personal and professional development in order to recover lost ground (Blau 
and DeVaro, 2007). Women are then more likely to return to work in part-time roles which may necessitate taking a backwards step into their careers (Blau and DeVaro, 2007). Hochschild (2012) argues that there is a division of labour associated with 'men's' and 'women's' work, with women undertaking 'caring' or 'nurturing' work and men undertaking roles which require a colder emotional approach. In addition, women are more likely to be subject to direct or indirect discrimination in their working lives (Peterson and Morgan, 1995).

The expectations of motherhood play an important role, requiring women to conform (Nilson, 2015; Güney-Frahm, 2020). Such an idealised image begins during pregnancy and continues post-birth, encompassing the caring role, healthy role and working role. A possible impact of the COVID-19 pandemic is that the combination of these roles is unattainable as a result of social isolation (Güney-Frahm, 2020). The onset of the COVID19 pandemic has acted to exacerbate the disparity between genders by putting pressure on women to achieve unattainable socio-economic goals (Güney-Frahm, 2020). In the context of Higher Education having to meet these expectations could lead to an increased sense of failure, whether perceived or actual. These neoliberalist views of motherhood roles act to increase inequalities (Wang and Inoue, 2020; Yildirim and Eslen-Ziya, 2020).

Research notes that the COVID-19 pandemic led to an increase in women as the main care provider alongside and to some extent created by working from home as an employee (Wang and Inoue, 2020). This included women as the main provider of childcare, including the provision of home-schooling in real-time adding to the burden. Women primarily undertake domestic chores, such as cooking and cleaning, tasks which are more intense during the lockdown period due to increased occupancy in the home (Aldossari and Chaudhry, 2021). The COVID-19 pandemic has accelerated change in working practices such that the volume of work rapidly increasing. In Higher Education for example, teaching and learning activities had to be taken rapidly online, which required additional training to learn the use of new technologies relevant to remote teaching. In addition, teaching pedagogies also had to be adapted to facilitate remote learning which also contributed to the volume of work rapidly increasing.

Research conducted by Yildirim and Eslen-Ziya (2020) demonstrated that the day-to-day routine of female academics with children was disproportionately affected by the COVID-19 pandemic. In addition, women with children are academically less productive than men (Collins et al., 2020; Lutter and Schröder, 2020). This could relate to the conflict between the demands of both roles, where women must prioritise childcare. In family units with children, where the man is the main financial provider, the women is expected to undertake additional roles that the man cannot. Arguably, the COVID-19 pandemic has required an increase in the need for 'caring' work which Hochschild argues is more likely to be undertaken by women (2012). This may have placed an additional burden, as this work is allocated or delegated disproportionately to female members of staff (Hochschild, 2012). COVID-19 has been at the top of Higher Education agendas for the last 12 months. Although there are established policies promoting gender equality, these have been deprioritised. This may not have been a conscious decision but time, energy and resources have been diverted (Yildirim and Eslen-Ziya, 2020).

\section{Development Activities and Career Progression}

Where boundaries between home and work are blurred women may feel greater levels of stress and workplace burnout (Clark et al., 2020). In addition, to domestic tasks, stress can also originate in the workplace, through for example direct or indirect discrimination or lack of opportunity to gain promotion (Doyle and Hind, 1998; Knights and Richards, 2003). To mitigate this woman may move into less demanding roles or reduce hours at work (Connolly and Gregory, 2008; Wheatley, 2013). Higher Education has taken steps to support employees during the COVID-19 pandemic, including putting in place remote working arrangements (Nash and Churchill, 2020). Nash and Churchills (2020) research conducted in Australia, showed that whilst flexible working arrangements were often in place, these were not necessarily consistently applied. The impact could be a view that caring responsibilities are exceptional rather than the norm. An unintended consequence is that caring responsibilities become hidden, overlooked and thus not deemed institutional priorities (Acker, 2006).

Working mothers were reported to work an increasing number of hours in order to meet the demands of childcare and the workplace during the lockdown phase of the COVID-19 pandemic (Jessen and Waights, 2020). This could suggest there is limited time for additional activities such as those required for career development, as the focus is on what is perceived as essential or core tasks. Andersen et al. (2020) research denoted that the research activities between men and women differed. For example, they reported that $19 \%$ fewer women were named as first author when compared to the same time in the previous year. In addition, Kitchener (2020) and Viglione (2020) presented anecdotal evidence suggesting women submitted fewer papers to peer-reviewed journals, compared to men.

Aldossari and Chaudhry (2021) noted the difference in how men and women see the transformed spaces; where men see home as a restorative place whereas women see it as a place of unpaid work, which may have led to feelings of inadequacy and burnout. Inappropriate or unsuitable spaces to conduct work, or having to work unsociable hours when children are asleep has added to the burden (Clark et al., 2020; Nash and Churchill, 2020). The COVID-19 pandemic has arguably led to women losing resources available to them and subsequently increasing vulnerability to further losses, when compared to men (Peck 2020). These losses could be in relation to loss of earnings, or loss of a job and highlights a resource poor position women held, relative to men, prior to the COVID-19 pandemic (Connolly and Gregory, 2008; Wheatley, 2013). Academic productivity is measured in part by the number of peer reviewed submissions. This found a reduction in women submitting publications, whereas men remained unaffected by the COVID-19 pandemic (Anderson et al., 2020; Collins et al., 2020; Lutter 
and Schröder, 2020). Productivity also encompasses aspects of teaching and learning, which women may have conducted at unsociable times to reduce interruptions (Jessen and Waights, 2020). Similar gender gaps were noted in broader populations, indicating the COVID-19 pandemic has far reaching implications for women in the workplace (Collins et al., 2020).

\section{DISCUSSION}

This paper explores the impact of the COVID-19 pandemic on women working in academia, in particular the disproportionate care burden of women resulting from the dispersed and isolated family unit (Jessen and Waights, 2020). Research has highlighted how the reality of working at home has disproportionally impacted women with children. Quite simply, there is more childcare to do, occupied houses require more cleaning and meal preparation that cannot be completed by anyone else. The gender gap has widened with these competing demands (Alon et al., 2020; Biroli et al., 2020; Carlson et al., 2020; Costoya et al., 2020; Power, 2020). The expectations of these roles and the constraints surrounding them, including who should perform them, may change the construct of motherhood (Güney-Frahm, 2020). As a result women have had to prioritise motherhood in order to fulfil an idealised role (Collins et al., 2020; Lutter and Schröder, 2020). This is likely to lead to a reduction in productivity in their paid role and close career pathways. A consequence may be a reversal of the progress in gender equality agendas in Higher Education (Yildirim and EslenZiya, 2020). Disruption to the boundaries between work and home are likely to continue in the short to medium term.

Therefore, moving forward Higher Education employers must consider the impact of the COVID-19 pandemic on women with childcare responsibilities (Nash and Churchill, 2020). Higher Education employers must ensure maximum flexibility for staff in terms of when and how work is undertaken. This may help women to restructure the time when work is undertaken and allow that to be weaved in between childcare tasks. Given that this paper concludes that the overall workload of women has increased, they must be able to contribute by working outside of traditional working hours and locations, with all of the associated patriarchal connotations. In their internal communication strategies Higher Education employers should strive to create a culture where nonstandard working hours and locations are accepted, embracing new ways of working. This should perpetuate cultural change away from the traditional concept of working hours which by its nature disadvantages women who are having to provide childcare. More work is needed in this area to ensure that initiatives, whilst well intended, deliver. Higher Education employers should undertake equality impact assessments both prior to and importantly after such initiatives are put in place.

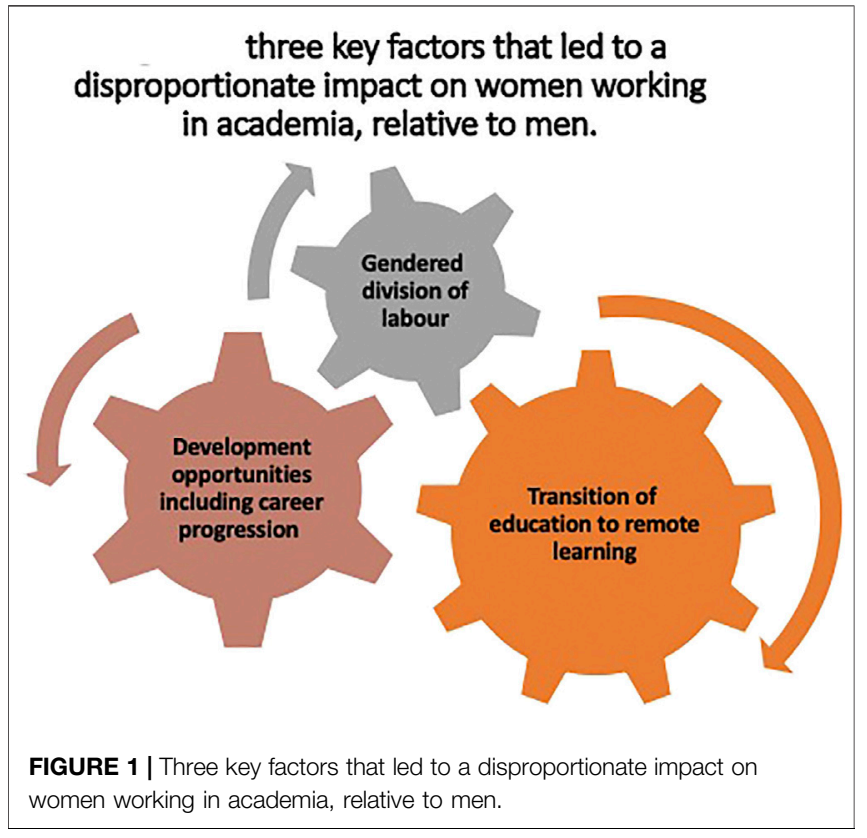

This paper has explored three key factors that led to a disproportionate impact on women working in academia, relative to men. These three key factors focus on the roles and responsibilities of the transition of education to remote learning, development opportunities, including career progression and the gendered division of labour, including caring responsibilities (see Figure 1). The findings indicate the gender gap in the context of domestic tasks and factors that may influence career development. Further research is required into the long-term consequences of the COVID-19 pandemic on women working in higher education. This is limited to a comparison of men and women, pre and post COVID-19, further work should be carried out to understand the effect on other groups and importantly, intersectionality. This work should for example aim to understand the impact on single sex or trans parents. Further work also needs to be carried out to understand the level of disadvantage that motherhood places within Higher Education relative to other groups.

\section{AUTHOR CONTRIBUTIONS}

The author confirms being the sole contributor of this work and has approved it for publication.

\section{ACKNOWLEDGMENTS}

Thank you to Gabriela Misca for her encouragement. 


\section{REFERENCES}

Acker, J. (2006). Inequality Regimes. Gend. Soc. 20 (4), 441-464. doi:10.1177/ 0891243206289499

Aldossari, M., and Chaudhry, S. (2021). Women and Burnout in the Context of a Pandemic. Gender Work Organ. 28 (2), 826-834. doi:10.1111/gwao.12567

Alon, T., Doepke, M., Olmstead-Rumsey, J., and Tertilt, M. (2020). The Impact of COVID-19 on Gender Equality. Available at: https://ideas.repec.org/p/bon/ boncrc/crctr224_2020_163.html (Accessed December 31, 2020).

Andersen, J. P., Nielsen, M. W., Simone, N. L., Lewiss, R., and Jagsi, R. (2020). Meta-research: COVID-19 Medical Papers Have Fewer Women First Authors Than Expected. Available at: https://arxiv.org/ftp/arxiv/papers/2005/2005. 06303.pdf (Accessed December 31, 2020).

Biroli, P., Bosworth, S. J., Della, G., Di Girolamo, A., Jaworska, S., and Vollen, J. (2020). Family Life in Lockdown. Available at: https://www.iza.org/ publications/dp/13398/family-life-in-lockdown (Accessed December 31, 2020).

Blau, F. D., and DeVaro, J. (2007). New Evidence on Gender Differences in Promotion Rates: an Empirical Analysis of a Sample of New Hires. Ind. Relations 46, 511-550. doi:10.1111/j.1468-232x.2007.00479.x

Carlson, D. L., Petts, R., and Pepin, J. R. (2020). Changes in Parents' Domestic Labor during the COVID-19 Pandemic. SocArXiv. doi:10.31235/osf.io/jy8fn Available at: https://osf.io/preprints/socarxiv/jy8fn (Accessed December 15, 2020).

Clark, S., McGrane, A., Boyle, N., Joksimovic, N., Burke, L., Rock, N., et al. (2020). 'You're a Teacher You're a Mother, You're a Worker': Gender Inequality during Covid-19 in Ireland, Gend. Work Organ. 28 (S1), 1-11. doi:10.1111/gwao.12611

Collins, C., Landivar, L. C., Ruppanner, L., and Scarborough, W. J. (2020). COVID19 and the Gender Gap in Work Hours. Gend. Work Organ. 28 (S1), 549-560. doi:10.1111/gwao.12506

Connolly, M., and Gregory, M. (2008). The Part-time Pay Penalty: Earnings Trajectories of British Women. Oxford Econ. Pap. 61 (1), i76-i97. doi:10.1093/oep/gpn043

Costoya, V., Echeverría, L., Edo, M., Rocha, A., and Thailinger, A. (2020). The Impact of COVID-19 in the Allocation of Time within Couples. Available at: https://ideas.repec.org/p/sad/wpaper/145.html (Accessed December 15, 2020).

Cui, R., Ding, H., and Zhu, F. (2020). Gender Inequality in Research Productivity during the COVID-19 Pandemic. Available at: https://arxiv.org/abs/2006 (Accessed December 15, 2020).

Doyle, C., and Hind, P. (1998). Occupational Stress, Burnout and Job Status in Female Academics. Gend. Work Organ. 5 (2), 67-82. doi:10.1111/1468-0432.00047

Guatimosim, C. (2020). Reflections on Motherhood and the Impact of COVID 19 Pandemic on Women's Scientific Careers. J. Neurochem. 155, 469-470. doi:10. $1111 /$ jnc. 15158

Güney-Frahm, I. (2020). Neoliberal Motherhood during the Pandemic: Some Reflections. Gend. Work Organ. 27, 847-856. doi:10.1111/gwao.12485

Hochschild, A., and Machung, A. (2012). The Second Shift: Working Families and the Revolution at Home. New York, NY: Penguin.

Hochschild, A. R. (2012). The Managed Heart: Commercialization of Human Feeling. London: University of California Press.
Jessen, J., and Waights, S. (2020). Effects of COVID-19 Day Care Centre Closures on Parental Time Use: Evidence from Germany. Available at: https:/voxeu.org/article/covid-19-day-care-centre-closures-and-parental-time-use (Accessed December 15, 2020).

Kitchener, C. (2020). Women Academics Seem to Be Submitting Fewer Papers during Coronavirus. 'Never Seen Anything like it,' Says One Editor. The Lily, Available at: https://www.thelily.com/women-academics-seem-tobesubmitting-fewer-papers-during-coronavirus-never-seen-anything-likeitsays-one-editor/ (Accessed December 15, 2020).

Knights, D., and Richards, W. (2003). Sex Discrimination in UK Academia. Gend. Work Org. 10 (2), 213-238. doi:10.1111/1468-0432.t01-1-00012

Lutter, M., and Schröder, M. (2020). Is There a Motherhood Penalty in Academia? the Gendered Effect of Children on Academic Publications in German Sociology. Eur. Sociological Rev. 36 (3), 442-459. doi:10.1093/esr/jcz063

Minello, A. (2020). The Pandemic and the Female Academic. Nature 28 (4), [Epub ahead of print]. doi:10.1038/d41586-020-01135-9

Nash, M., and Churchill, B. (2020). Caring during COVID-19: A Gendered Analysis of Australian University Responses to Managing Remote Working and Caring Responsibilities. Gend. Work Organ. 27, 833-846. doi:10.1111/gwao.12484

Nilson, K. (2015). Towards a Radical Re-appropriation: Gender, Development and Neoliberal Feminism. Develop. Change 46 (4), 803-832.

Peterson, T., and Morgan, L. A. (1995). Separate and Unequal: OccupationEstablishment Sex Segregation and Gender Wage Gap. Am. J. Sociol. 101, 329-365.

Power, K. (2020). The COVID-19 Pandemic Has Increased the Care Burden of Women and Families. Sustainability: Sci. Pract. Pol. 16 (1), 67-73. doi:10.1080/ 15487733.2020.1776561

Viglione, G. (2020). Are women publishing less during the pandemic? Here's what the data say. Nature 581, 365-366. doi:10.1038/d41586-020-01294-9

Wang, V., and Inoue, M. (2020). When Can We Go to School? Nearly 300 Million Children Are Missing Class. Available at: https://www-nytimes-com. apollo.worc.ac.uk/2020/03/04/world/coronavirus-schools-closed.html (Accessed December 15, 2020).

Wheatley, D. (2013). Location, Vocation, Location? Spatial Entrapment Among Women in Dual Career Households. Gend. Work Organ. 20 (6), 720-736.

Yildirim, T. M., and Eslen-Ziya, H. (2020). The Differential Impact of COVID-19 on the Work Conditions of Women and Men Academics during the Lockdown. Gend. Work Organ. 28 (S1), 691-697. doi:10.1111/gwao.12529

Conflict of Interest: The author declares that the research was conducted in the absence of any commercial or financial relationships that could be construed as a potential conflict of interest.

Copyright (c) 2021 Augustus. This is an open-access article distributed under the terms of the Creative Commons Attribution License (CC BY). The use, distribution or reproduction in other forums is permitted, provided the original author(s) and the copyright owner(s) are credited and that the original publication in this journal is cited, in accordance with accepted academic practice. No use, distribution or reproduction is permitted which does not comply with these terms. 